\title{
PENGGUNAAN MEMBRAN KITOSAN UNTUK MENURUNKAN KADAR LOGAM KROM PADA LIMBAH INDUSTRI PENYAMAKAN KULIT
}

\author{
Sholeh Ma'mun ${ }^{1}$, Marhaenia Theresa $^{2}$, Sarah Alfimona ${ }^{3}$ \\ Jurusan Teknik Kimia, Fakultas Teknologi Industri, Universitas Islam Indonesia ${ }^{1,2,3)}$ \\ Jl. Kaliurang Km. 14,5 Yogyakarta 55584 \\ Email :sholeh.mamun@uii.ac.id ${ }^{l}$
}

\begin{abstract}
Membrane made of chitosan from shrimp shell can be used to reducea heavy metal chromium (Cr) content in leathertanning industry waste by adsorption. The membranes were manufactured from chitosan with concentrations of 2, 3, and $4 w t \%$, respectively. In addition, glycerol was added during membrane manufacturing as an additive to increase the permeability properties. The results showed that themembrane with $2 \%$ chitosan without glycerol gave the best adsorption performance. However, increased the chitosan concentration showed a negative effect to the membrane performance in adsorbing the chromium due to chitosan solubility limitation in the acetic acid. However, the use of glycerol did not improve the adsorption performance. This was due to hydrophilic property of the glycerol.
\end{abstract}

Keywords : Chitosan Membrane, Glycerol, Chromium, Leather Tanning Industry.

\section{PENDAHULUAN}

Industri penyamakan kulit merupakansalah satu industri yang menghasilkan limbah yang cukup berbahaya bagi lingkungan berupa pencemaran air, tanah dan udara.Industri penyamakan kulitini menghasilkan limbah cair yang mengandung sisa bahan penyamak kimia seperti natrium sulfida, krom, kapur, dan amoniak dalam jumlah yang cukup besar.

Air buangan limbah industri penyamakan kulit umumnya mengandung logamkrom yang berasal dari proses penyamakan dengan menggunakan senyawa krom sulfat antara 60-70\%. Namun demikian, pada proses penyamakan tersebut, tidak semua larutan krom sulfat terserap oleh kulit, sehingga sisanya dikeluarkan dalam bentuk limbah cair. Keberadaan krom dalam limbah cair penyamakan kulit dengan kadar yang tinggi dapat menyebabkan pencemaran lingkungan dan berdampak buruk bagi kesehatan. Kelebihan krom dalam tubuh akan mengakibatkan berbagai gangguan pada kulit, saluran pernafasan, ginjal, dan hati. Disamping itu, limbah krom trivalent akan menimbulkan masalah jika teroksidasi menjadi ion krom ber valensi enam (heksavalen) yang bersifat toksik. Selain itu, industri penyamakan kulit juga menghasilkan limbah padat yang menimbulkan bau menyengat karenaadanya pembusukan berbagai sisa kulit dan daging terutama lemak dan protein.

Pada umumnya cara pengolahan limbah yang sering dilakukan adalah cara kimia dan fisika. Pengolahan limbah secara kimia dilakukan dengan cara pengendapan pada $\mathrm{pH}$ tinggi dengan penambahan bahan kimia tertentu, sedangkan pengolahan secara fisika dilakukan dengan cara adsorpsi, koagulasi, flokulasi, dan filtrasi (Crini, 2005).

Beberapa metode lain seperti penukar ion, adsoprsi dengan karbon aktif (Devi dan Naidu, 1990) dan pengendapan secara elektrolisis telah dilakukan untuk menyerap bahan pencemar beracun dari limbah cair, tetapi cara ini membutuhkan biaya yang sangat tinggi dalam pengoperasiannya. Sementara itu, penggunaan bahan biomaterial dan non biomaterial sebagai penyerap ion logam berat merupakan sebuah alternatif yang cukup menjanjikan. Biomaterial yang telah digunakan antara lain lumut (Low dkk., 1977), daun teh (Tee dan Khan, 1989) dan sabut kelapa sawit (Munaf 
dan Zein, 1999), sedang kannon biomaterial seperti perlit, tanah gambut, dan lumpur aktif.

Dalam penyerapannya, setiap metode memiliki keunggulan dan keterbatasan masing - masing dari aspek teknis, ekonomis dan dampak yang ditimbulkannya. Oleh karena itu perlu dikembangkan suatu alternatif sistem pemisahan logam berat dan buangannya dengan menggunakan bahanbahan yang relatif murah dan cukup ketersediaannya.

Sementara itu prinsip daur ulang dapat dilakukan dengan pemanfaatan limbah suatu industri menjadi bahan baku oleh industri lain dan menghasilkan suatu produk baru, contohnya limbah kulit udang dari industri pengolahan udang yang dapat diolah menjadi kitin yang kemudian menjadi kitosan.

Kitosan merupakan senyawa yang tidak larut dalam air, sedikit larut dalam $\mathrm{HCl}$, $\mathrm{HNO}_{3}$, dan $\mathrm{H}_{3} \mathrm{PO}_{4}$, tetapi tidak larut dalam $\mathrm{H}_{2} \mathrm{SO}_{4}$. Kitosantidak beracun, mudah mengalami biodegradasi dan bersifat polielektrolitik (Hirano,1986). Disamping itu, kitosan dapat dengan mudah berinteraksi dengan zat - zat organik lainnya, misalnya dengan protein. Oleh karena itu, kitosan relatif lebih banyak digunakan pada berbagai bidang industri terapan dan industri kesehatan (Muzzarelli, 1986).

Adanya kandungan logam berat di perairan dapat berbahaya baik secara langsung terhadap kehidupan organisme maupun secara tidak langsung terhadap kesehatan manusia. Hal ini berkaitan dengan sifat - sifat logam berat (PPLH-IPB, 1997; Sutamihardja dkk., 1982) yaitu : (1) sulit didegradasi, sehingga mudah ter akumulasi dalam lingkungan perairan dan keberadaannya secara alami sulit terurai dan (2) dapat terakumulasi dalam organisme termasuk kerang dan ikan, sehinggaakan membahayakan kesehatan manusia yang mengkomsumsi organisme tersebut.

Pada saat ini penelitian tentang pemanfaatan polimer alam sebagai membran sedang berkembang dengan bahan membran dari selulosa dan turunannya. Selain membran selulosa dan turunannya, karakterisasi membran kitin untuk tujuan analisis telah dilakukan oleh Tarigan (2005). Sementara itu, Dyahningtyas (1999) telah memanfaatkan kitosan untuk menghilangan Kadmium (Cd). Penelitilainnya yang memanfaatkan kitosan untuk penjerapan logam berat antara lain Franco dkk. (2004), Manurung (2005), Munaf dan Zein (1999), Tee dan Khan (1989), dan lain - lain.

Penelitian ini bertujuan untuk membuat membran kitosan yang digunakan untuk mengolah limbah cair dari industri penyamakan kulit untuk menurunkan kadar krom, sehingga setelah dilakukan pengolahan kualitas limbah cair tersebut dapat memenuhi baku mutu air limbah yang telah ditetapkan Menteri Lingkungan Hidup nomor 5 Tahun 2014 dengan maksimal kadar krom sebesar $0,6 \mathrm{mg} / \mathrm{L}$ untuk industri penyamakan kulit.

\section{METODE PENELITIAN}

\subsection{Alat dan Bahan}

Pada percobaan ini digunakan alatalatantara lain : gelas beker, labu takar, gelas ukur, corong gelas, cawan arloji, cawan petri, pipet tetes, pipet volume, pengaduk,dan timbangan analitik.

Bahan utama yang digunakan adalah kitosan dari kulit udang dan limbah cair industri penyamakan kulit dengan bahan pembantu antara lain asam asetat $\left(\mathrm{CH}_{3} \mathrm{COOH}\right)$, natrium hidroksida $(\mathrm{NaOH})$, dan gliserol. Sementara itu, instrumen yang digunakan dalam penelitian ini adalah Atomic Adsorption Spectrofotometri (AAS).

\subsection{Prosedur Penelitian}

Kedalam 2 buah gelas beker yang masing - masing berisi $100 \mathrm{~mL}$ larutan asam asetat $1 \%$ ditambahkan $2 \mathrm{~g}$ kitosan (2\% kitosan). Pada gelas beker pertama ditambahkan $2 \mathrm{~mL}$ gliserol, sedangkan yang kedua tanpa gliserol. Kedua campuran kemudian diaduk selama 2 jam hingga homogen. Selanjutnya kedua larutan itu dibiarkan selama 24 jam. Larutan kemudian dituangkan ke dalam sebuah cawan petri untuk mencetak membran. Membran yang telah dicetak tersebut kemudian dikeringkan 
di oven pada suhu $60^{\circ} \mathrm{C}$ selam 2 hari. Setelah kering, lapisan membran ditambahkan $\mathrm{NaOH} 1 \%$ dan didiamkan hingga membran terangkat kepermukaan. Kemudian dilakukan pencucian berulang - ulang menggunakan aquades untuk menghilangkan $\mathrm{NaOH}$. Prosedur yang sama juga diterapkan untuk pembuatan membran kitosan dengan konsentrasi 3 dan $4 \%$.

\subsection{Perlakuan dan Analisa Limbah Cair dengan Membran Kitosan}

Membran kitosan dimasukkan ke dalam kolom dan disusun sehingga memenuhi seluruh permukaan kolom. Selanjutnya sebanyak $15 \mathrm{~mL}$ sampel limbah dialirkan ke dalam kolom, kemudian didiamkan berkontak selama 3 jam. Setelah itu, hasil penyerapan ditampung dalam gelas ukur dan dimasukan kedalam botol sampel untuk dianalisis menggunakan AAS.

\section{HASIL DAN PEMBAHASAN}

Berdasarkan Perda DI Yogyakarta No. 7 Tahun 2016 bahwa baku mutu limbah industri penyamakan kulit untuk logam krom sebesar $0,5 \mathrm{mg} / \mathrm{L}$ kadar maksimal, sedangkan kadar krom dalam limbah yang digunakan dalam penelitian ini sebesar 58,5 $\mathrm{mg} / \mathrm{L}$, sehingga belum memenuhi baku mutu limbah yang ditentukan. Dengan demikian, diperlukan langkah - langkah untuk menurunkan kadar krom dalam limbah tersebut, salah satunya dengan cara disaring menggunakan membran yang terbuat dari kitosan seperti yang telah dikerjakan dalam penelitian ini.

Membran dibuat dengan melarutkan kitosan ke dalam asam asetat dan dilakukan dua perlakuan, yang pertama larutan kitosanasam asetat ditambah gliserol dan yang kedua larutan kitosan - asam asetat tanpa gliserol dengan konsentrasi kitosan 2,3, dan $4 \%$.

Pencampuran dilakukan menggunakan pengaduk magnetik dengan kecepatan dan suhu tetap. Terlihat bahwa semakin tinggi jumlah kitosan yang terlarut dalam asam asetat maka semakin lama pengaduk berputar dan campuran semakin kental. Hal ini menunjukan adanya kejenuhan dalam larutan tersebut. Pengadukan pada proses pelarutan dilakukan untuk mendapatkan larutan kitosan yang homogen sehingga menghasilkan membran dengan ukuran dan distribusi pori yang seragam. Akan tetapi selama proses pengadukan mungkin terdapat udara yang terperangkap di dalam larutan. Oleh sebab itu larutan didiamkan selama 24 jam untuk proses degassing yaitu menghilangkan udara yang terperangkap di dalam larutan. Selanjutnya, membran di keringkan pada suhu $60^{\circ} \mathrm{C}$ selama dua hari, sehingga diperoleh membran yang kering.

Selanjutnya, ke-enam membran tersebut digunakan untuk menyaring limbah cair penyamakan kulit dengan kadar logam krommula-mulasebesar 58,5 $\mathrm{mg} / \mathrm{L}$. Hasil pengujian kadar logam kromtersisa di dalam limbah dengan menggunakan AAS dapat dilihat pada tabel 1 dan gambar 1 .

Tabel 1. Hasil Uji Kadar Logam Kromtersisa (mg/L) di Dalam Limbah Pada Berbagai Konsentrasi Kitosan

\begin{tabular}{ccccccc}
\hline \multicolumn{7}{c}{ Hasil Uji } \\
\hline $\mathrm{X}$ & A.1 & A.2 & B.1 & B.2 & C.1 & C.2 \\
58,5 & 5,83 & 1,13 & 11,6 & 1,35 & 18,6 & 1,38 \\
\hline
\end{tabular}

\section{dimana:}

$\mathrm{X}=$ sampel limbah.
A. $1=2 \%$ kitosan + gliserol.
A. $2=2 \%$ kitosan.
B.1 $=3 \%$ kitosan + gliserol.
B. $2=3 \%$ kitosan.
C. $1=4 \%$ kitosan + gliserol.
C. $2=4 \%$ kitosan.

Dari gambar 1 terlihat bahwa penyerapan logam krom yang paling tinggi diperoleh pada konsentrasi kitosan 2\% tanpa menggunakan gliserol (A.2). Kemampuan kitosan untuk mengikat logam dengan cara pengkhelat disebabkan karena kadar nitrogen yang tinggi pada rantai polimernya. Kitosan mempunyai satu kumpulan amino linier bagi setiap unit glukosa. Kumpulan amino ini mempunyai sepasang elektron yang dapat berkoordinat atau membentuk ikatan - ikatan aktif dengan kation - kation logam. Unsur nitrogen pada setiap monomer kitosan 
dikatakan sebagai gugus yang aktif berkoordinat dengan kation logam.

Titik optimum dalam penyerapan logam krom terjadi pada konsentrasi kitosan 2\%. Hal ini dikarenakan kitosan masih bisa terlarut sempurna dalam asam asetat. Pada konsentrasi kitosan 3 dan 4\%, kemampuan penyerapan logam membran kitosan semakin berkurang, dikarenakan pada konsentrasi tersebut kitosan sudah dalam keadaan jenuh sehingga sebagian kitosan tidak terlarut dalam asam asetat.

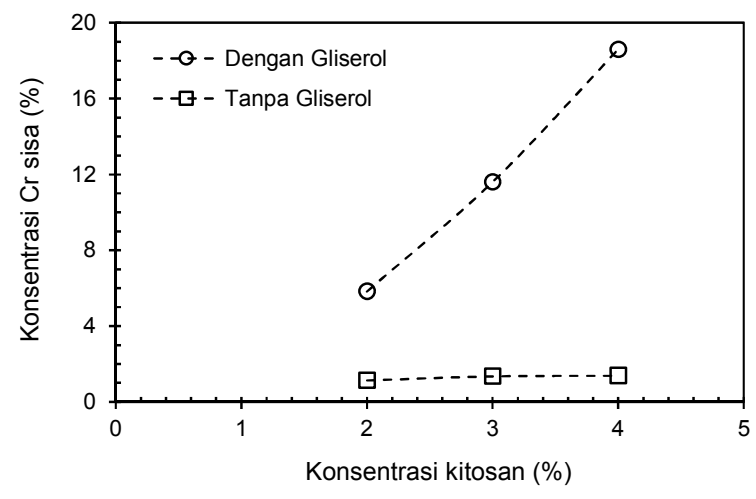

Gambar 1. Hubungan Antara Konsentrasi

Krom Sisa Dalam Sampel Dengan

Konsentrasi Kitosan Dengan dan Tanpa Gliserol.

\subsection{Pengaruh Konsentrasi Kitosan terhadap Lama Penguapan}

Untuk membran dengan konsentrasi kitosan $2 \%$, terlihat bahwa asam asetat yang terlarut lebih cepat menguap karena kitosan larut dengan sempurna dalam asam asetat. Namun untuk membran dengan kadar kitosan 3\%, zat terlarut dalam pelarut semakin meningkat, maka titik didih meningkat pula, sehingga proses penguapan lebih lama. Sedangkan pada pelarutan dengan kadar kitosan $4 \%$ terjadi titik jenuh sehingga masih terdapat gumpalan gumpalan kitosan yang mengakibatkan proses penguapan menjadi lebih lama.

\subsection{Pengaruh Konsentrasi Kitosan terhadap Daya Serap}

Marganof (2003) telah menganalisis kemampuan kitosan sebagai adsorben logam - logam berat seperti cadmium (Cd), timbal $(\mathrm{Pb})$, krom $(\mathrm{Cr})$, tembaga $(\mathrm{Cu})$, dan nikel (Ni). Kemampuan kitosan menyerap logam logam tersebut dikarenakan adanya sifat sifat kitosan yang dihubungkan dengan gugus amino dan hidroksil yang terikat, sehingga menyebabkan kitosan mempunyai reaktifitas kimia yang tinggi dan menyebabkan sifat poli elektrolit kation. Akibatnya kitosan dapat berperan sebagai penukar ion (ion exchanger) dan dapat berperan sebagai adsorben terhadap logam berat dalam air limbah. Dengan menvariasikan konsentrasi kitosan, dari tabel 1 terlihat bahwa konsentrasi kitosan 2\% memberikan daya serap terhadap logam krom tertinggi yaitu sekitar $98 \%$.

\subsection{Pengaruh Gliserol terhadap Daya Serap}

Membran yang baik adalah membran yang mempunyai fouling rendah, berstruktur tipis tapi kuat, dan mempunyai daya serap yang baik. Salah satu cara yang digunakan untuk meningkatkan kinerja membran adalah dengan menambahkan zat aditif, seperti polietilen glikol (PEG), sedangkan untuk meningkatkan sifat mekanik membran dapat ditambahkan titanium dioksida $\left(\mathrm{TiO}_{2}\right)$.

Variabel lain dalam penelitian ini yaitu membuat membran kitosan dengan campuran gliserol yang ditambahkan pada saat proses pelarutan kitosan. Dari hasil pengamatan terlihat bahwa membran kitosan dengan penambahan gliserol mempunyai struktur yang lebih kuat akan tetapi mengakibatkan daya serap membran menurun. Hal ini dikarenakan gliserol memiliki sifat hidrofilik sehingga pada saat penyerapan logam berat membran tersebut cenderung menyerap $\mathrm{H}_{2} \mathrm{O}$. 


\section{KESIMPULAN}

Dari hasil penelitian ini dapat disimpulkan bahwa membran kitosan 2\% tanpa gliserol mempunyai kinerja penyerapan logam krom tertinggi yaitu sekitar 98\%. Sedangkan penambahan gliserol pada membran kitosan mempunyai efek negatif terhadap daya serap membran pada logam krom.

\section{Ucapan Terima Kasih}

Penulis mengucapkan terima kasih kepada Jurusan Teknik Kimia atas ijin dan fasilitas sehingga penelitian dapat diselesaikan tepat waktu.

\section{DAFTAR PUSTAKA}

Crini, G. Recent Development in Polysaccharide - based Materials Used as Adsorbents in Wastewater Treatment. Progress in Polymer Sciencec 30, 38-70, 2005.

Devi, P. R. and Naidu, G. R. K. Enrichment of Trace Metals in Water on Activated Carbon. Analyst. 115: 1469-1471, 1990.

Dyahningtyas, T.E. Penghilangan Kadmium (Cd) dengan Menggunakan Chitosan, Prosiding Seminar Nasional Kimia V, Laboratorium Kimia Anorganik FMIPA UGM Yogyakarta,8-9 Maret 1999, 1999.

Franco, L. O., Maia, R.C., Porto, A.L.F., Messias, A.S., Fukushima, K., and Campos-Takaki, G.M. Heavy Metal Biosorption by Chitin and Chitosan Isolated from Cunninghamella elegans (IFM 46109), Braz.J.Microbiol., 35 (3) 2004.

Hirano, S., 1986. Chitin and Chitosan. In Ulmann's Encyclopedia of Industrial Chemistry. Republic of Germany. $5^{\text {th }}$ ed. A6: $231-232$.

Low, K.S., Lee, C.K.,Tan, S.G. Sorption of Trivalent Chromium from Tannery Waste by Moss. Juornal Environmental Technology. $18:$ 449-454, 1997.
Manurung, M. Penggunaan Kitosan Manik sebagai Adsorben untuk Menurunkan Kadar Logam Ni. Skripsi Universitas Sumatera Utara, Medan, 2005.

Marganof. Potensi Limbah Udang sebagai Penyerap Logam Berat (Timbal, Kadmium, dan Tembaga) di Perairan (www.tumoutu.net/70207134/margonof. $p d f$ ). Diakses tanggal 15 Oktober 2016, 2003.

Munaf, E. dan Zein, R.. Pemanfaatan Sabut Kelapa Sawit untuk Menyerap Ion Logam Kadmium dan Krom dalam Air Limbah. Jurnal Kimia Andalas. 5 (1) : $10-14,1999$.

Muzzarelli, R.A.A. Chitin. Faculty of Medicine Univeersity of Ancona. Italy. Pergamon Press. 81-87, 1986.

Sutamihardja, R.T.M., Adnan, K. dan Sanusi. Perairan Teluik Jakarta Ditinjau dari Tingkat Pencemarannya. Fakultas Pascasarjana, Jurusan PSL. IPB, 1982.

Tarigan, T. Pembuatan Membran Kitin dan Pegujian Sifat Permeabilitas Terhadap Ureum, Aspirin dan Albumin. Tesis Program Pasca Sarjana Universitas Sumatera Utara, Medan, 2005.

Tee, T. W. and Khan, A. R. M. Removal of Lead, Cadmium and Zinc by Waste Tea Leaves. Journal Environmental Technology. 9: 1223-1232, 1989. 